\title{
Activities for Promoting Interactive Learning and its Educational Effects
}

\author{
Yoshinori Naruse \\ University of Toyama, Japan
}

\begin{abstract}
The use of active learning and information and communications technologies (ICT) in classes is extremely effective for encouraging students to take the initiative in solving given tasks. Interactive learning and group work should be used in class to raise students' independent and active learning attitudes. Students can learn deeply through class activities of presenting their opinions to one another while respecting and referring to them. Especially, evaluation activities influence the effectiveness of their interactive learning. This paper presents a description of interactive learning using evaluation activities and describes observations of their educational effects. Moreover, teachers should experience the meanings of interactive learning and ICT use education to develop students' active attitudes and various abilities and skills. This paper also presents teacher training using the same type of interactive learning that is employed in students' classes. The author investigated teacher awareness of interactive learning. Results show that teachers learned the importance of active learning for students. ICT is recommended for use in developing students' interactive learning.
\end{abstract}

\section{Introduction}

Teachers in Japan are expected to have skills for using Information and Communication Technologies (ICT) in class, and to promote active learning [1][2]. Actually, teachers used to convey knowledge to students using traditional one-way teaching. Students used to conduct their experiments neither deciding their studying tasks before launching their work nor finding solutions from their tasks by themselves. Students merely followed an experimental manual to confirm the results of their experiments. Reportedly, such traditional teaching and learning methods did not lead students to acquire necessary abilities to be found in their tasks, to decide a procedure to solve them, or to attain their goals [3][4][5].

The Japanese New Educational Guideline is slated for application in schools starting in 2020. To prepare for that future, Japanese teachers should use new approaches to improve students' skills to discover their own tasks, consider them by themselves, and execute them using appropriate measures.
Several approaches to active learning have been demonstrated by teachers in Japan. The Ministry of Education, Culture, Sports, Science and Technology, Japan (MEXT) has reported that proactive learning, dialogic interaction and deep considerations are extremely important to promote active learning [6]. Actually, MEXT has suggested that ICT enables classes to be more active, and enables students to consider matters more deeply.

The use of ICT in class has four purposes: to improve students' ICT skills, to improve basic academic skills, to stimulate group work, and to enrich students' understanding. The purpose of active learning is to encourage students to learn how to take the initiative in solving given tasks [7]. Students' group work and their interactive learning activities should be promoted to achieve these purposes.

Students' interactive learning should be promoted through the effective use of ICT and through introduction of active learning in class. Therefore, interactive learning has drawn the attention of many researchers. Various educational practices have been applied in classes using an interactive learning method. Many studies have examined educational systems in which students work for a given task with others and solve it. However, the educational effects of such systems have not been investigated fully.

Teachers understand the theoretical importance of active learning, interactive learning, and the use of ICT in classes. Nevertheless, they have not experienced the effectiveness of active learning and ICT use directly and personally. Many teachers who adopt active learning in their classes compel students merely to work together without understanding the importance of interactive learning. For that reason, teachers or students hoping to become educators must acknowledge that ICT is useful for active learning, and must acknowledge that an interactive mode of learning is effective for gaining new knowledge and for deepening consideration of a given task.

This paper reports details of how the author conducted several educational activities related to interactive learning to enhance teachers' comprehension of the effectiveness and importance of students' interactive learning. The subjects of the activities were in-service teachers and students who wished to be teachers in the near future. The author conducted activities of two kinds: educational activities using immediacy of ICT and trial lessons exploiting two evaluation activities. After a course of 
activities, a survey was distributed to them to ascertain what abilities and skills they obtained through those educational activities. Especially, the latter activities were fundamentally important to recognize the importance of evaluation.

Two evaluation activities exist: self-assessment and assessment by others. Activities were conducted for in-service teachers and students hoping to become educators. The two evaluation activities were conducted to develop students' interactive learning. Students had a lesson in which the importance of selfevaluation and self-evaluation items were explained to them.

Students reflected on their activities and examined them objectively by themselves. Later, students evaluated their activities using self-evaluation items. Other students in the classroom also evaluated the student activities. In fact, every student evaluated others in the classroom using the same self-evaluation items. Some students realized that several items were more highly evaluated by others than by their selfassessment. This report describes these two valuation activities.

\section{Immediacy of ICT and interactive learning}

\subsection{Purpose of ICT use for interactive learning}

Teachers are requested to consider two points: what ICT should be used effectively in class and what activity in class needs use of ICT. An important aspect of the use of ICT in class is collecting students' opinions instantaneously and sharing their opinions among students. These results enable students to recognize the status of their opinions in their whole classroom [8][9].

The author has offered students as many opportunities as possible so that students are able to express their own opinions in a group of several persons, or present their ideas to other students in front of the classroom. Students reflected on themselves independently at the end of each lesson, and wrote what they learned during the lesson, as well as what problems were left unresolved. Results show that students recognized that listening to other students' opinions was very useful. They also requested to collect more information related to other students' views. Students teaching each other by themselves and learning from others is very effective. In these situations, teachers devote themselves to supporting students to the last. If students maintain motivation to know more, their learning will develop.

The author conducted classroom activities in which students would recognize other students' opinions. Students can analyze their own ideas by presenting their opinions to others. Okada [10] reports that, while carrying out teachers' practical training program studying social skills for education, participants must acquire a better understanding through their familiar examples and practical experiences. Okada also emphasized the ineffectiveness of conducting a teacher training program that is filled with many contents in a short time.

In conducting interactive learning, the author organized educational activities using students' familiar examples so that they were able consider a task matching with their own experiences. The feature of the interactive learning was to secure sufficient time for students to discuss matters among themselves and consider deeply a task during the lesson because their voting results were shown immediately in the classroom using ICT.

\subsection{Class activities and results}

A salient educational benefit of ICT use in the classroom is that it offers students' immediate responses to teachers. The author conducted educational activities using an e-learning system. Information ethics was a discussion topic of the activities. Results show that it is useful for students to consider a topic through concrete examples and to clear their thoughts. Moreover, they can deepen their thoughts further by being instructed by a teacher in how to consider the topic. Therefore, the author first gave students a topic related to information ethics. Then the students considered how to approach the topic.

After students watched a two-minute video related to the topic, they thought about several problems presented in the video and considered how a main character in the video should make a good decision in a situation. Three solutions were explained to students using the e-learning system.

1. The main character should discuss the problem with persons who caused the problem.

2. The main character should discuss the problem with persons who were adversely affected by the problem.

3. The main character should consult with teachers about the problem.

Then students chose one solution from the three. Student choices were collected and presented to them instantly. Students grasped a tendency of their choices. Teachers explained several difficulties that might arise from each solution. Students then made groups of two or three, discussed the problems in groups and deepened their understanding. The same three solutions were presented to students again. Students chose one solution among the three and reflected upon the results. In this way, interactive learning was introduced to the class to develop students' understanding. 
Results of votes cast on the first day were presented to students immediately: $55 \%$ of students chose 1 , $39 \%$ of students chose 2 , and $6 \%$ of students chose 3 . Teachers explained problems that might arise from each solution. They asked students to consider this topic again in their groups. Students chose one of the three solutions again. Finally, students' three solutions were presented to the students once more.

The results were displayed on the screen: $44 \%$ of students chose $1,31 \%$ of students chose 2 , and $28 \%$ of students chose 3. Some students changed their opinions and chose different solutions. At the end of the lesson, students reflected on what they learned and wrote their findings on the Learning Management System (LMS) using free writing. Consequently, results showed that students were very positive in understanding other students' thoughts instantly.

They realized that discussion in their group and listening to others' opinions were very effective for organizing their thoughts. Some students wrote that they were able to use ICT easily in the class, although they had thought that ICT must have been extremely difficult. However, after their practices, they found out that it was much easier than they had expected.

By contrast, many students reported that ICT should be used at appropriate times to advance their lessons effectively in class. Interactive learning activities were conducted in this lesson. Such interaction enabled students to realize differences between their own opinions and others' opinions through reflection upon their self-evaluation.

\section{Six contents of classes for interactive learning}

Following the processes shown below, teachers teach many classes at K-12 schools in Japan.

1. Reviewing the prior lesson with a teacher

2. Showing a task assignment to be solved during the day's lesson and explaining it to students

3. Considering the given task independently

4. Considering the task in groups and discussing it

5. Presenting each group idea

6. Summarization by teachers and showing an applied problem to students

7. Reflection on their learning

8. Announcing the next lesson to students

Reportedly, students were able to face their learning task actively and acquire an interactive attitude by working in groups through the eight activities described above. Some researchers specifically emphasized the eight learning activities, and reported that students enhanced their learning motivation and made their group work active when each student clearly understood the meaning of a learning task. Students learned the following six activities to improve their teaching skills (Table 1).
Table 1. Contents of class activities for interactive learning

1 Activities to collect and arrange ideas for a given task in person

2 Activities to collect and arrange ideas for a given task in groups

3 Activities to produce teaching materials using ICT

4 Activities to carry out trial lessons using ICT

materials developed by teachers

5Activities to evaluate trial lessons by self-

evaluation and evaluation by others

6 Activities to learn theories and concepts from other teachers

(1) Activities to collect and arrange ideas for a given task in person

Students understand the meaning of a given task assignment or a task assignment that they found by themselves. Next, they confirm what must be resolved related to the task. They analyze the task in person and clarify what they do not understand or what opinions they have related to the task. These are learners' independent activities.

(2) Activities to collect and arrange ideas for a given task in groups

After students collect their own ideas or opinions related to the task, they discuss the task in a group of four persons. The rules of students' discussion are given to them in advance to avoid a situation in which only one student keeps speaking to other students in their group or one particular student does not participate in speaking activities.

The purpose of making the rule is to compel and encourage students to express their opinions actively and to collect as many opinions as they can from other students in their group.

(3) Activities to produce teaching materials using ICT

Effective use of ICT in the classroom promotes the efficiency of student learning and deepens their understanding. Considering how and when to use ICT in class, students produce ICT materials for appropriate scenes of the day's lesson.

(4) Activities to carry out trial lessons using ICT materials developed by teachers

Students conduct a trial lesson with other students in their group for 5 min using ICT materials originally produced by students. It is a very short trial lesson. However, before their trial lesson, students are required to explain three points to other students: when to use ICT materials in the lesson, what activities to do using ICT, and the purpose of using ICT materials. After their simulated lessons, discussion time is prepared for students to collect comments and questions from other students in their groups.

(5) Activities to evaluate trial lessons by selfevaluation and evaluation by others 
After the lessons, reflection time is also given to students. They evaluate their trial lessons using selfevaluation items and collect evaluation from other students who observe the trial lessons. They write their comments for the trial lessons on the LMS.

(6) Activities to learn theories and concepts from other teachers

Teachers explain their theories or concepts related to their teaching such as a lesson's framework, effectiveness of ICT materials and group learning characteristics.

\section{Abilities motivated by interactive learning}

The goal of interactive learning is to improve students' abilities: 1 Planning ability and creating ability, 2 Cooperation and initiative, 3 ICT skills, 4 Ability for self-analysis and quality improvement, and 5 Presentation skills.

(1) Teachers observe students' academic achievement, cooperation, and initiative in class. They should also consider how to prepare effective lessons and devise teaching procedures. Teachers must learn necessary educational theories and practical approaches so that they can produce lessons from a heightened perspective and so that they can produce teaching plans based on the theories and several educational approaches. These skills are designated as planning ability and creation ability.

(2) Recently the "school as a team" idea has been accepted at schools in relation to cooperation and initiative. Teachers have felt it difficult to manage school-based issues independently for years. In addition, various support and influences are fundamentally important to develop the necessary qualities and abilities of students. Teachers should also take the initiative in coping with educational issues in cooperation with local people and specialists related to various problems.

(3) ICT skills refer to teachers' skills at producing teaching materials using ICT and use ICT in classes effectively. ICT skills are defined here as skills to make better use of ICT: for example, they include computer knowledge and programming skills to produce teaching materials using presentation software, to give presentations to students using tablet terminals and to present images usefully with projectors.

(4) Abilities of self-analysis and quality improvement are useful to analyze lessons objectively and to liven up class activities. Teachers should reflect upon their classes from several perspectives and revise their lessons independently. Teachers carry out open classes to invite other teachers. These open classes give teachers opportunities to analyze classes objectively with some help from other teachers' evaluation. In this way, teachers increase abilities of self-analysis. They can improve the quality of their lessons.

(5) Presentation skills are necessary because teachers very often speak in front of students, explain their ideas or opinions to other teachers clearly, and sometimes discuss school events and issues with parents and local people. Presentation skills are fundamentally important for teachers.

\section{Trial lessons including evaluation activities and educational effects}

The author conducted a four-month course for inservice teachers. Details of activities for selfevaluation and evaluation by others are described next. This activity was conducted with 13 in-service teachers and students wishing to become a teacher in the near future. Teachers created their ICT materials. Each teacher gave a trial lesson for ten minutes in their group. When trial lessons finished, they evaluated tenminute trial lessons using five evaluation items: 1 Display of lesson goals and check of learning attitude, 2 Clarity of learning processes, 3 Preparation of thinking time, 4 Confirmation of learning contents, and 5 Application of learning contents.

After evaluation activities were completed, the author presented the two evaluation results to the teachers in the course: self-evaluation by each teacher and evaluation by observers in a trial lesson. It is worthwhile to reflect on class activities objectively. Self-reflection strengthens the abilities of selfanalysis and quality improvement. Evaluating other teachers' activities also cultivates abilities of selfevaluation. The author explained the usefulness of evaluation activities to teachers in the course after they had experienced self-evaluation and evaluation by other teachers in the course.

Examination using a Wilcoxon signed rank test was done. Table 2 presents the results. Teachers exchanged mutual evaluations with other teachers. For 1. Display of lesson goals and checking of learners' attitudes, a difference was found at the $0.1 \%$ significance level according to the mean values of self-evaluation and evaluation by others. For 2 . Clarity of learning process a difference was found at the $1 \%$ significance level according to the mean values of self-evaluation and evaluation by others.

These results demonstrate that the values of selfevaluation are lower than those of evaluation by others, and that in-service teachers evaluated their own classes very strictly. These results also suggest that self-evaluation and evaluation by others are extremely effective because teachers read the results of evaluation by others for reference when they evaluated themselves. Consequently, they recognize what they did not notice by themselves and understood what they should revise, after reviewing evaluations by others. 
Yabe [11] reports four elements of self-evaluation: they are self-purpose, self-activity, self-evaluation, and self-reinforcement. He also adds that students do evaluation by themselves so that they can make their decisions autonomously and strengthen themselves through reflection on their learning activities and studying by themselves.

Table 2. Differences of mean values between selfevaluation and evaluation by others

\begin{tabular}{|c|c|c|c|c|c|}
\hline \multirow[b]{2}{*}{ Evaluation Items } & \multicolumn{2}{|c|}{ Evaluation by others } & \multicolumn{2}{|c|}{ Self-evaluation } & \multirow[b]{2}{*}{$p$} \\
\hline & $\begin{array}{l}\text { Mean } \\
\text { Value }\end{array}$ & $\begin{array}{l}\text { Standard } \\
\text { Deviation }\end{array}$ & $\begin{array}{l}\text { Mean } \\
\text { Value }\end{array}$ & $\begin{array}{l}\text { Standard } \\
\text { Deviation }\end{array}$ & \\
\hline $\begin{array}{l}1 \text { Display of lesson goals and } \\
\text { check of learners' attitude }\end{array}$ & 4.15 & 0.43 & 3.54 & 0.66 & $.002 * *$ \\
\hline 2 Clarity of learning process & 4.14 & 0.41 & 3.46 & 0.88 & $.028 *$ \\
\hline 3 Preparation of thinking time & 4.48 & 0.35 & 4.08 & 0.49 & .055 \\
\hline 4 Confirmation of learning contents & 4.19 & 0.61 & 3.62 & 0.87 & .093 \\
\hline 5 Application of learning contents & 3.94 & 0.71 & 3.38 & 0.87 & .116 \\
\hline
\end{tabular}

The coefficients of correlation among activities for evaluation were investigated. Results of coefficients of correlation among activities for evaluation by others are shown in Table 3. According to the result, Pearson's correlation coefficient showed a strong degree of correlation between 1 Display of lesson goals and check of learners' attitudes and 4 Confirmation of learning contents, and among 4 Confirmation of learning contents, 2 Clearness of learning process, and 5 Application of learning contents.

Teachers who confirm students' learning attitudes tend to confirm student learning contents at the end of lessons. Teachers who try to clarify their learning process tend to give students some application of learning contents, which suggests that teachers can recognize how they should conduct lessons better by receiving others' evaluation sheets and then analyzing their own lessons to ascertain some points which they had not noticed by themselves. Therefore, lesson studies are extremely useful for teachers.

Table 3. Coefficients of correlation among activities for evaluation by others

\begin{tabular}{|c|c|c|c|c|c|}
\hline Variables & $\begin{array}{l}1 \text { Display of } \\
\text { lesson goals and } \\
\text { check of } \\
\text { learners' attitude }\end{array}$ & $\begin{array}{l}2 \text { Cleamess of } \\
\text { learning process }\end{array}$ & $\begin{array}{l}\text { 3 Preparation of } \\
\text { thinking time }\end{array}$ & $\begin{array}{l}4 \text { Confirmation } \\
\text { of learning } \\
\text { contents }\end{array}$ & $\begin{array}{l}5 \text { Application of } \\
\text { learning } \\
\text { contents }\end{array}$ \\
\hline $\begin{array}{l}1 \text { Display of lesson goals } \\
\text { and check of learners' }\end{array}$ & 1.00 & 0.49 & 0.39 & $0.76^{* *}$ & $0.57^{*}$ \\
\hline $\begin{array}{l}2 \text { Clearness of learning } \\
\text { process }\end{array}$ & 0.49 & 1.00 & $0.57^{*}$ & $0.57^{*}$ & $0.82^{* *}$ \\
\hline $\begin{array}{l}3 \text { Preparation of thinking } \\
\text { time }\end{array}$ & 0.39 & $0.57 *$ & 1.00 & 0.30 & $0.65^{*}$ \\
\hline $\begin{array}{l}4 \text { Confirmation of learning } \\
\text { contents }\end{array}$ & $0.76^{* * *}$ & $0.57^{*}$ & 0.30 & 1.00 & $0.62^{*}$ \\
\hline $\begin{array}{l}5 \text { Application of learning } \\
\text { contents }\end{array}$ & $0.57^{*}$ & $0.82^{* * *}$ & $0.65^{*}$ & $0.62^{*}$ & 1.00 \\
\hline
\end{tabular}

\section{Self-evaluation and evaluation by others for in-service teachers}

In-service teachers in the course independently evaluated the five skills described above after they had taken 15-week classes. Before the first lesson began and after the last lesson had finished, they assessed how much they improved their skills according to a five-scale evaluation system: 5 extremely much, 4 very much, 3 neither, 2 not much, 1 not at all. Results presented in Table 4 suggest that four skills were improved significantly: 1 Planning ability and creating ability, 3 ICT skills, 4 Ability in self-analysis and quality improvement, and 5 Presentation skills.

Examination using a Wilcoxon signed rank test was done next. Results show that the students' awareness for 3 ICT skills and 4 Ability in selfanalysis and quality improvement were raised at the $1 \%$ significance level. Moreover, the students' awareness for 1 Planning ability and creating ability and 5 Presentation skills were raised at the 5\% significance level.

Results show that activities to collect and arrange ideas for a given task in person, activities to collect and arrange ideas for a given task in groups, activities to produce teaching materials using ICT, activities to carry out trial lessons using ICT materials developed by teachers, activities to evaluate trial lessons by selfevaluation and evaluation by others, and activities to learn theories and concepts from other teachers can improve students' abilities such as planning ability, creating ability, ICT ability, presentation skills, and abilities for self-analysis and quality improvement.

Table 4. Self-evaluation of abilities and skills

\begin{tabular}{|c|c|c|c|c|c|}
\hline \multirow{2}{*}{ Abilities } & \multicolumn{2}{|c|}{ Before the first class } & \multicolumn{2}{|c|}{ After the last class } & \multirow[b]{2}{*}{$p$} \\
\hline & $\begin{array}{l}\text { Mean } \\
\text { Value }\end{array}$ & $\begin{array}{l}\text { Standard } \\
\text { Deviation }\end{array}$ & $\begin{array}{l}\text { Mean } \\
\text { Value }\end{array}$ & $\begin{array}{l}\text { Standard } \\
\text { Deviation }\end{array}$ & \\
\hline 1 Planning and creating abilities & 2.77 & 0.73 & 3.46 & 0.52 & 0.011 \\
\hline 2 Cooperativeness and initiative & 3.69 & 0.48 & 3.77 & 0.44 & 0.317 \\
\hline 3 ICT skills & 2.77 & 1.17 & 3.77 & 0.73 & 0.003 \\
\hline $\begin{array}{l}4 \text { Abilities for self-analysis and } \\
\text { quality improvement }\end{array}$ & 2.62 & 0.51 & 3.54 & 0.66 & 0.003 \\
\hline 5 Presentation skills & 2.77 & 0.93 & 3.38 & 0.77 & 0.023 \\
\hline
\end{tabular}

\section{Educational Effects on Interactive Learning}

It is meaningful for teachers to have the capability to analyze activities and to deepen their ability of selfanalysis by being evaluated by others. The author first explained the importance of evaluation activities for self-evaluation and evaluation by others to in-service teachers in the course. They analyzed what class activities would be effective to raise the five skills in 
the table. They examined various activities and categorized them into the following six activities:

First, the author asked in-service teachers and students to choose useful activities sufficient to raise the five skills. They can choose multiple activities for each skill. Results are presented below (Table 5). Numbers respectively represent percentages of inservice teachers who think it is sufficient to raise skills.

1 "Activities to collect and arrange ideas for a given task in person" are associated with raising planning ability and creating ability.

2 "Activities to collect and arrange ideas for a given task in groups" are associated with raising cooperation and initiative.

3 "Activities to make teaching material with use of ICT" are associated with raising ICT skills.

4 "Activities to carry out a trial lesson using ICT materials developed by teachers" are associated with raising planning ability and creating ability, and raising ability in self-analysis and quality improvement.

5 "Activities to evaluate trial lessons by selfevaluation and evaluation by others" are associated with raising ability in self-analysis and quality improvement.

6 "Activities to learn theories and concepts from other teachers" are associated with raising abilities in selfanalysis and quality improvement, and ICT skills.

These six results were inferred from the teachers' evaluation activities. Overall, in-service teachers in the course realized that "Activities to collect and arrange ideas for a given task in groups" and "Activities to learn theories and concepts from other teachers" raised the levels of various skills.

Table 5. Useful learning activities to improve students' abilities

\begin{tabular}{|c|c|c|c|c|c|c|}
\hline \multirow{2}{*}{ Ablities } & \multirow[b]{2}{*}{$\begin{array}{l}\text { Activities to } \\
\text { collect and } \\
\text { arrange ideas } \\
\text { for a given } \\
\text { task in person }\end{array}$} & \multirow[b]{2}{*}{$\begin{array}{l}2 \text { Activities to } \\
\text { collect and } \\
\text { arrange ideas } \\
\text { for a given } \\
\text { task in groups }\end{array}$} & \multicolumn{2}{|l|}{ Activities } & \multirow[b]{2}{*}{$\begin{array}{l}5 \text { Activities to } \\
\text { evaluate trial } \\
\text { lessons with } \\
\text { self-evaluation } \\
\text { and evaluation } \\
\text { by others }\end{array}$} & \multirow[b]{2}{*}{$\begin{array}{l}6 \text { Activities to } \\
\text { learn theories } \\
\text { and concepts } \\
\text { from other } \\
\text { teachers }\end{array}$} \\
\hline & & & $\begin{array}{l}3 \text { Activities to } \\
\text { produce } \\
\text { teaching } \\
\text { materials using } \\
\text { ICT }\end{array}$ & $\begin{array}{l}4 \text { Activities to } \\
\text { carry out a } \\
\text { trial lesson } \\
\text { using ICT } \\
\text { materials } \\
\text { developed by } \\
\text { teachers }\end{array}$ & & \\
\hline $\begin{array}{l}\text { 1. Planning and creating } \\
\text { abilities }\end{array}$ & 0.62 & 0.46 & 0.62 & 0.46 & 0.15 & 0.46 \\
\hline $\begin{array}{l}\text { 2. Cooperativeness and } \\
\text { initiative }\end{array}$ & 0.15 & 0.69 & 0.08 & 0.15 & 0.31 & 0.23 \\
\hline 3. ICT skills & 0.08 & 0.08 & 0.77 & 0.54 & 0.38 & 0.54 \\
\hline $\begin{array}{l}\text { 4. Abilities for self-analysis } \\
\text { and quality improvement }\end{array}$ & 0.38 & 0.54 & 0.31 & 0.08 & 0.62 & 0.62 \\
\hline 5. Presentation skills & 0.31 & 0.54 & 0.08 & 0.54 & 0.31 & 0.46 \\
\hline
\end{tabular}

\section{Conclusions}

Japanese K-12 education requires interactive learning activities because the possibility exists for students to create new ideas through collaborative work and to deepen their understanding through interaction and reflection. Results of many lesson studies have indicated that students can learn deeply through class activities that include presentation of their opinions to each other, respecting and referring to them. The author found that teachers do not necessarily have sufficient experience with the meanings of interactive learning and ICT use education.

As described in this paper, the author investigated evaluation activities and class activities to promote student learning. Next, teachers were given teacher trainings including the same type of classes including interactive learning. The author investigated teacher awareness for interactive learning. Results show that teachers were able to learn that active learning is important for students. ICT is recommended for use in developing students' interactive learning.

\section{References}

[1] Ministry of Education, Culture, Sports, Science and Technology, Japan (2016), http://www.mext.go.jp/b_menu/ shingi/chukyo/chukyo3/053/siryo/_icsFiles/afieldfile/201 6/08/02/1375316_1_1.pdf, 2016. (Last Access: 02 September 2017)

[2] N. Fujishiro, I. Miyaji, (2009) 'Effectiveness of Blended Instruction in Class on the Skills of Oral Reading and Speaking in English', Educational Technology Research, 32(1), pp. 79-90.

[3] M. Prince (2004) 'Does Active Learning Work? A Review of the Research', Journal of Engineering Education, Vol.93, No.3, pp.223-231.

[4] Y. Naruse, I. Miyaji, S. Toga, Y. Hayase, and Y. Hayakawa, (2013) 'Educational Effect on Analyzing Others' Experimental Products', Proceedings of Society for Information Technology \& Teacher Education International Conference, U.S.A., pp. 3996-4000.

[5] S. Freeman, S. L. Eddy, M. McDonough, M. K. Smith, N. Okoroafor, H. Jordt, and M. P. Wenderoth (2014) 'Active learning increases student performance in science', engineering, and mathematics, Proceedings of the National Academy of Sciences of the United States of America, 111 (23), pp.8410-8415.

[6] Ministry of Education, Culture, Sports, Science and Technology, Japan (2016), http://www.mext.go.jp/b_menu/ shingi/chukyo/chukyo0/toushin/_icsFiles/afieldfile/2017/ 01/10/1380902_0.pdf. (Last Access: 02 September 2017)

[7] Y. Naruse (2009) 'A Study on the Class of Learning Optimal Decision Making Using AHP', Journal of the Japan Society of Educational Information 25(1), pp. 25-35.

[8] Y. Mizuochi, J. Nishikawa (2003) 'Indirect Transmission of Computer Literacy by Making Visible Other Student's Learning Situation', Japan Journal of Educational Technology, 27, Suppl., pp. 177-180.

[9] M. Suzuki, (2016) 'The relationship between "manabiai" and active learning in National Institutes of Technology', The Bulletin of National Institute of Technology, Kisarazu College, 49, pp. 79-82.

[10] Y. Okada (2016) 'Trial Study on Practice and Evaluation of Teacher Training Program for Social Skills 
International Journal for e-Learning Security (IJeLS), Volume 7, Issue 2, September 2017/18

Education', Japan Journal of Educational Technology, 39 (Suppl.), pp. 133-136.

[11] T. Yabe (2000) 'A Study on Formation of SelfEvaluation Ability in School Mathematics: Some factors in formation of self-evaluation ability and its framework', Journal of Japan Society of Mathematical Education, 82(4), pp. 40-49. 